\title{
Experimental Escherichia coli peritonitis in immunosuppressed mice: the role of specific and non- specific immunity
}

\section{J. VUOPIO-VARKILA}

\section{National Public Health Institute, Mannerheimintie 166, SF-00280 Helsinki, Finland}

\begin{abstract}
Summary. An experimental Escherichia coli septicaemia-peritonitis model was adapted to immunosuppressed mice. The mice were made neutropenic by a sublethal dose of cyclophosphamide, which resulted in a 100 -fold increase in their susceptibility to intraperitoneal injection of $E$. coli $\mathrm{O} 18: \mathrm{K} 1$. A lethal infection could be prevented by passive immunisation with anti-K 1 capsular or anti-O18 LPS antibodies but not with anti-J 5 bacterial antibodies. The anti-K 1 and anti-O18 antisera were able to increase the LD50 of the E. coli challenge by factors of 50 and 5, respectively. The role of nonspecific, lipopolysaccharide (LPS)-mediated resistance to infection was also investigated in this model, in which only long-living phagocytic cells such as macrophages are believed to be functional. Pretreatment of mice with LPS was shown to prevent growth of the bacterial challenge in the peritoneal cavity and blood and to result in a five-fold increase in the LD50 of the challenge strain. These findings suggest an important role for macrophages as effector cells in defence against $E$. coli infection.
\end{abstract}

\section{Introduction}

Systemic infections with gram-negative bacilli are a major risk for hospitalised patients with serious underlying disease. Immunosuppressive chemotherapy further increases this risk (Weinstein et al., 1983 $a$ and $b$ ). To study these infections, their treatment and prevention, a recently described systemic mouse $E$. coli $\mathrm{O} 18: \mathrm{K} 1$ infection model (Nowicki et al., 1986; Vuopio-Varkila et al., 1987a) has been modified. Susceptibility to $E$. coli was increased by inducing neutropenia with an injection of cyclophosphamide. This is an alkylating agent, also used in human cancer chemotherapy, that acts primarily on short-lived cell types such as polymorphonuclear leukocytes (Petursson and Chervenick, 1982) and also on B-cells and, to a smaller extent, on T-cells or macrophages (Turk and Parker, 1982; Hunninghake and Fauci, 1976). Similar immunosuppression models have been reported for infections with Klebsiella spp. and Pseudomonas aeruginosa in dogs (Harvath and Andersen, 1976), rats (Lumish and Norden, 1976) and mice (Buhles and Shifrine, 1977; Trautmann et al., 1985).

Two different approaches to preventing this lethal $E$. coli infection are reported here, one by specific immunity induced by passive transfer of antisera, the other by induction of non-specific

Received 5 Jan. 1987; accepted 5 Mar. 1987. resistance. Passive immunisation of normal, immunocompetent mice with anti-K1 or anti-O18 antiserum protects against lethal $E$. coli O18:K1 peritonitis (Vuopio-Varkila et al., 1987a). It was, however, uncertain whether these antibodies could also protect neutropenic immunosuppressed mice.

Natural resistance to infection can also be increased by an injection of bacterial lipopolysaccharide (LPS) (Landy, 1956; Abernathy, 1957). Pretreatment of normal mice with $E$. coli K-12 LPS protects them from systemic infections caused by E. coli strains (Vuopio-Varkila et al., 1987b). This non-specific increase in resistance is primarily due to macrophage activation and to augmentation of their bactericidal capacity (Galelli et al., 1977). Whether or not such non-specific resistance to $E$. coli infection could also be induced in immunosuppressed mice was of great interest because of the high degree and wide spectrum of resistance achieved in normal mice.

\section{Materials and methods}

\section{Bacterial strains and culture conditions}

For mouse challenge, $E$. coli strain IH 3080 (serotype O18ac:K1:H7), isolated from human neonatal meningitis (Nowicki et al., 1986), was used. It was stored at $-70^{\circ} \mathrm{C}$ in skimmed milk until use. The log-phase inoculum for injection was prepared by growing the 
bacteria overnight in Luria broth (Miller, 1972) at $37^{\circ} \mathrm{C}$ on a rotary shaker, then diluting the culture 1 in 10 and growing for a further $120 \mathrm{~min}$ in similar conditions.

Strain J5 (Elbein and Heath, 1965) is a rough, UDPgalactose epimerase-deficient mutant of $E$. coli $\mathrm{O} 111$ obtained from Dr E. Ziegler, University of California, San Diego, CA, USA. E. coli strain DM 3219-54 (serotype O18ac:K5:H7) was from Drs F. and I. Orskov, Statens Serum Institut, Copenhagen, Denmark, and strain W 3350 was $E$. coli K-12 from Dr W. Brammar, University of Leicester, UK.

\section{Immunosuppression model}

Mice were given an intraperitoneal (ip) injection of a sublethal dose ( $300 \mathrm{mg} / \mathrm{kg}$ mouse body weight) of cyclophosphamide (CY) (Syklofosfamid, Lääke-Farmos, Turku, Finland) in a volume of $0.3 \mathrm{ml}, 48 \mathrm{~h}$ before infection. Blood leukocyte counts were determined in a haemocytometer, from blood samples drawn from the retro-orbital plexus of mice anaesthetised with ether at different times, to follow the immunosuppressive activity of CY treatment.

\section{Experimental infection}

$(\mathrm{CBA} \times \mathrm{C} 57 \mathrm{~B} 1 / 6) \mathrm{F} 1$ hybrid mice bred at this Institute (8-10 weeks old) were used in all assays. The bacterial challenge doses were 10 -fold dilutions of exponentiallygrowing E. coli $\mathrm{IH} 3080$ in $0.2 \mathrm{ml}$ of saline injected ip into groups of six mice. The LD50 was determined by the method of Reed and Muench (1938) from the day 5 survival data.

\section{Viable counts}

Samples were taken from the bacterial inoculum as well as from the peritoneal cavity and blood at different times (three mice at each time) for measuring the numbers of viable bacteria by plating series of dilutions on solid medium. The blood samples $(100 \mu \mathrm{l})$ were obtained from the retro-orbital plexuses of ether-anaesthetised mice. Thereafter the mice were killed by cervical dislocation and the peritoneal fluid harvested by injecting $2 \mathrm{ml}$ of saline ip and withdrawing a $500 \mu \mathrm{l}$ sample after gentle massage. The counts are given as $\mathrm{cfu} / \mathrm{ml}$ of fluid.

\section{Antisera}

Rabbit hyperimmune sera were obtained after immunisation of New Zealand White rabbits-four injections subcutaneously (sc) over a period of 6 weeks -with $10^{8}$ heat-killed bacteria per injection (Saxén and Mäkelä, 1982 ) and without adjuvant. The rabbits were bled 10 days after the last injection. The $\mathrm{K} 1$ capsule-specific hyperimmune serum of a horse (H46) immunised with Neisseria meningitidis group-B bacteria was a gift from Dr J. Robbins, NIH, Bethesda, MD, USA.

\section{Lipopolysaccharide preparation}

E. coli K-12 LPS was extracted by the phenolchloroform-petroleum ether method of Galanos et al. (1969), diluted in water and briefly sonicated before use.

\section{Passive immunisation}

Mice were passively immunised ip with $0.2 \mathrm{ml}$ of different dilutions of heat-inactivated $\left(56^{\circ} \mathrm{C}, 30 \mathrm{~min}\right)$ antisera, $2 \mathrm{~h}$ before bacterial challenge. Control animals were given saline.

\section{Lipopolysaccharide pretreatment}

Mice were given sc injections of $E$. coli K-12 LPS in a volume of $0.1 \mathrm{ml}, 24 \mathrm{~h}$ before bacterial challenge.

\section{Statistical method}

The significance of differences between the survival rates of controls and antiserum-treated mice was determined by Fisher's exact probability test (Swinscow, 1978).

\section{Results}

\section{The experimental infection in immunosuppressed} mice

A single ip injection of $\mathrm{CY}$ resulted in a severe leukopenia in the peripheral blood of the mice (fig. 1). The total blood leukocyte counts fell in $48 \mathrm{~h}$ from $6.9 \times 10^{6}$ cells $/ \mathrm{ml}$ in normal mice to $1.3 \times 10^{6}$ cells $/ \mathrm{ml}$ in the CY-treated mice, and the number of polymorphonuclear cells fell from $3.4 \times 10^{6}$ cells $/ \mathrm{ml}$ to $<0.5 \times 10^{6}$ cells $/ \mathrm{ml}$, a value corresponding to profound neutropenia in man. These low levels of leukocytes persisted from day 2 to day 7 . The total leukocyte number harvested from the peritoneal cavity also decreased from $6.0 \times 10^{6}$ cells $/ \mathrm{ml}$ to $2.7 \times 10^{6}$ cells $/ \mathrm{ml}$ by day 2 (data not shown). The experimental infection was, therefore, started on day 2 after injection of CY.

The LD50 of the challenge strain $E$. coli $\mathrm{O} 18: \mathrm{K} 1$ in the CY-treated mice was 100 -fold lower than in normal mice $\left(4 \times 10^{3}\right.$ versus $\left.4 \times 10^{5}\right)$ (fig. 2$)$. Most of the deaths in the CY-treated mice occurred 24 $72 \mathrm{~h}$ after challenge.

The kinetics of $E$. coli $\mathrm{O} 18: \mathrm{K} 1$ infection in the immunosuppressed mice resembled those in normal mice (Vuopio-Varkila et al., 1987a) (figs. 3 and 4). However, 100-fold smaller inocula given to CYtreated mice resulted in rapid growth of the bacteria in the peritoneal cavity and in subsequent appearance of viable bacteria in the blood. Bacteria were 


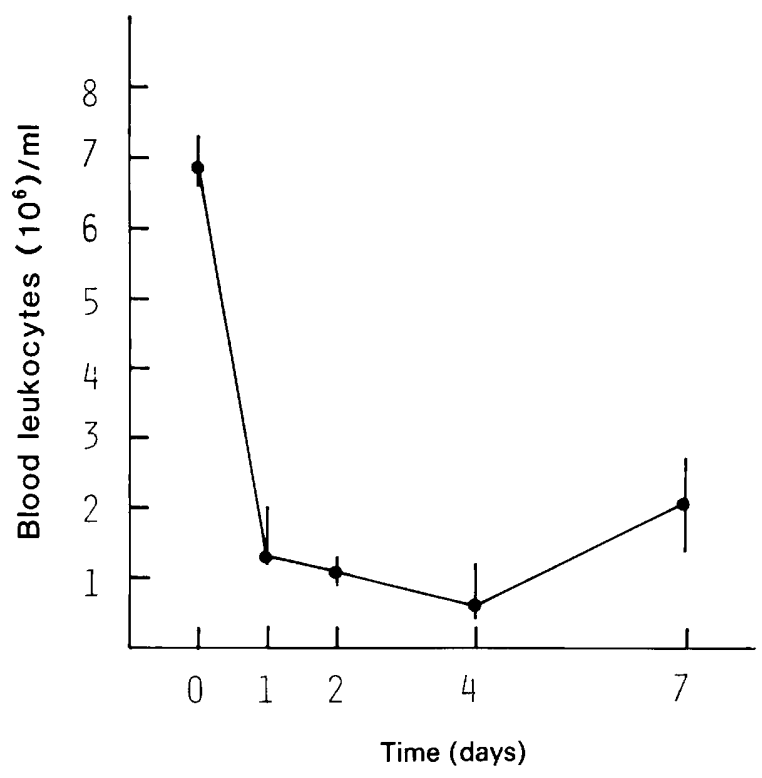

Fig. 1. The effect of CY treatment $(300 \mathrm{mg} / \mathrm{kg}$ ip at time 0$)$ on total peripheral blood leukocyte counts. The values at each time are means of at least five mice; the vertical lines show the ranges of values.

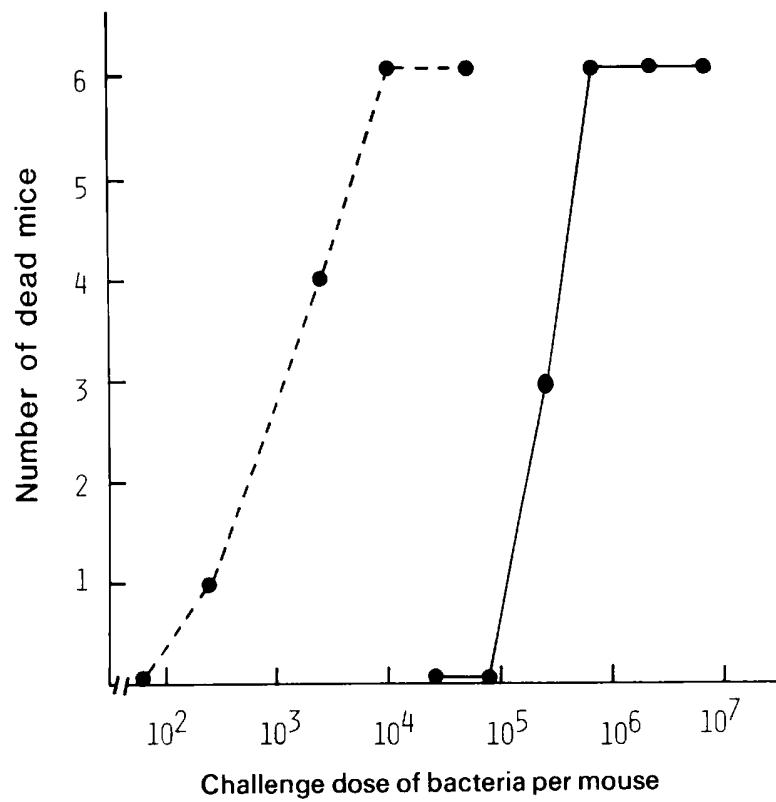

Fig. 2. The mortality dose-response curves in groups of six normal (- $\longrightarrow$ ) or immunosuppressed (---) mice, 5 days after challenge. The data for normal mice are taken from VuopioVarkila et al. (1987a).

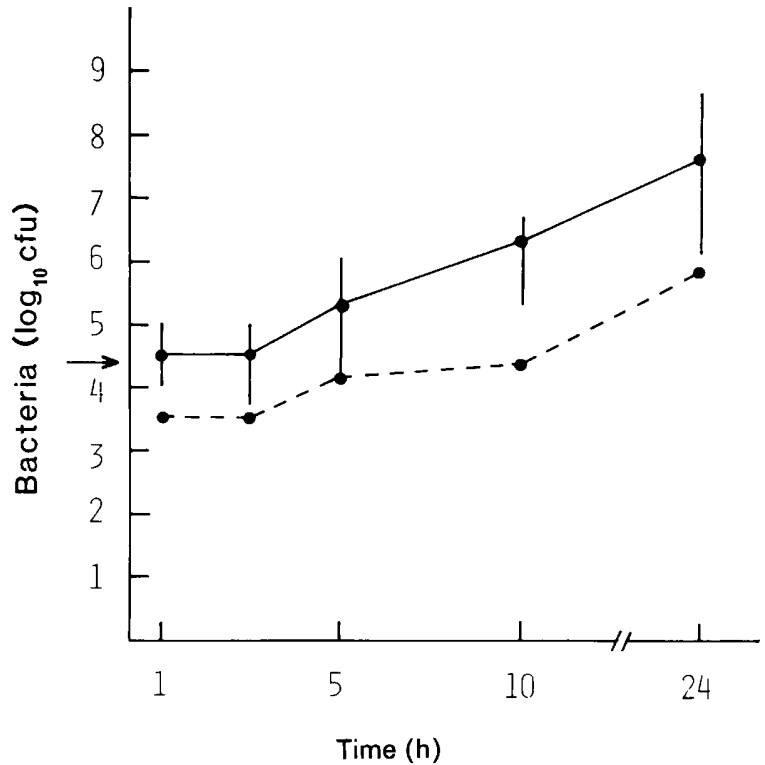

Fig. 3. The numbers of viable $E$. coli $\mathrm{O} 18: \mathrm{K} 1$ in the peritoneal cavity ( $\longrightarrow$ ) and blood (----) of immunosuppressed mice after ip challenge. The challenge dose, indicated by an arrow, was 5 LD50. Each point represents the geometric mean of results with three mice; the vertical lines show the ranges of values.

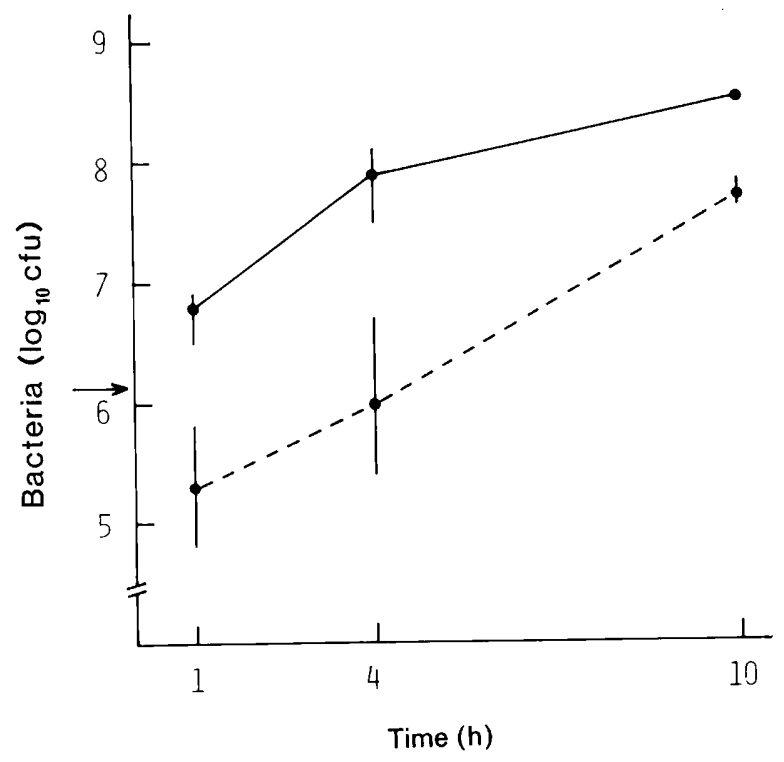

Fig. 4. The numbers of viable $E$. coli $\mathrm{O} 18: \mathrm{K} 1$ in the peritoneal cavity (- ) and blood (----) in normal mice after ip challenge. The challenge dose, indicated by an arrow, was 5 LD50. Each point represents the geometric mean of results with three mice; the vertical lines show the ranges of values. 
found in the liver and spleen at the same time as bacteraemia was detected; the counts in these organs by $24 \mathrm{~h}$ were $c .100$ times higher than in the blood (data not shown). With a dose of $2 \times 10^{4}$ bacteria (5 LD50) the generation time of the bacteria in the peritoneal cavity of the CY-treated mice during the early hours of infection was $45 \mathrm{~min}$, similar to the generation time in normal mice. Low inocula $(<1$ LD50) were cleared from the mice within $24 \mathrm{~h}$ of injection, with a reduction in the numbers of viable bacteria in the peritoneal cavity already apparent by $10 \mathrm{~h}$ (data not shown). When normal mice were given a challenge dose of $2 \times 10^{4}$ bacteria (only 0.05 LD50 for these mice), the bacteria were cleared from the peritoneal cavity within 24-36 h (data not shown).

\section{Passive immunisation}

Graded doses of antisera were injected into the immunosuppressed mice before challenge. Significant protection was observed with anti-K 1 capsular antiserum $(\mathrm{p}<0.001)$ and, to a lesser extent, with anti-O18 LPS antiserum $(p<0.02)$. The anti-K1 serum ( $\geqslant 0.2 \mu \mathrm{l} /$ mouse) raised the LD50 by a factor of 50 and the anti-O18 serum ( $\geqslant 20 \mu 1 /$ mouse) by a factor of 5. Three-fold smaller amounts of either serum did not give significant protection. Also, the kinetics of the infection in the serum-treated animals were similar in normal and immunosuppressed mice; the numbers of viable bacteria in the peritoneal cavities of mice that had received anti$\mathrm{K} 1$ serum decreased, within $60 \mathrm{~min}$ of challenge with $5 \mathrm{LD} 50$, to $1 \%$ of its initial value in normal mice and to $4 \%$ of the initial value in immunosuppressed mice (data not shown). This enhanced clearance was apparently enough to prevent the spread of the bacteria to the blood and other organs. The corresponding effect of the anti-O18 serum on bacterial numbers was somewhat less in both infection models (data not shown).

The anti-J5 serum did not protect the immunosuppressed mice from a lethal $E$. coli challenge (table I). This lack of effect corresponds to our previous studies with the $E$. coli infection model in normal mice in which antibodies to deeply-situated outer-membrane structures, such as the core glycolipid part of LPS, were not protective (VuopioVarkila et al., 1987a).

\section{Effect of LPS pretreatment}

When the mice were given sc injections of graded doses of $E$. coli $\mathrm{K}-12$ LPS $24 \mathrm{~h}$ after CY treatment and challenged $24 \mathrm{~h}$ thereafter with $E$. coli $\mathrm{O} 18: \mathrm{K} 1$,
Table I. Protective capacity of immune sera against $E$. coli peritonitis in immunosuppressed mice

\begin{tabular}{lccc}
\hline & & \multicolumn{1}{c}{$\begin{array}{c}\text { Number of mice dead/total } \\
\text { challenged (and percentage) } \\
\text { with dose }\end{array}$} \\
\cline { 3 - 4 } \multicolumn{1}{c}{$\begin{array}{c}\text { Type of } \\
\text { antiserum }\end{array}$} & $\begin{array}{c}\text { Amount of } \\
\text { serum }(\mu \mathrm{l})\end{array}$ & 5 LD50 & 50 LD50 \\
\hline $\begin{array}{l}\text { anti-K1-capsule } \\
\text { anti-O18-LPS }\end{array}$ & $0 \cdot 2$ & $2 / 15(13 \cdot 3)$ & $3 / 6(50 \cdot 0)$ \\
$\begin{array}{l}\text { anti-J5-bacteria } \\
\text { saline }\end{array}$ & 20 & $7 / 15(46 \cdot 6)$ & $4 / 6(66 \cdot 7)$ \\
& 200 & $9 / 12(75 \cdot 0)$ & NT \\
& & $11 / 12(91 \cdot 7)$ & $6 / 6(100)$ \\
\hline
\end{tabular}

an increase in resistance to infection was observed (table II). A dose of LPS $0.5 \mu \mathrm{g} /$ mouse resulted in a five-fold increase in LD50. A similar, although more effective, increase of non-specific resistance to $E$. coli $\mathrm{O} 18: \mathrm{K} 1$ challenge has been reported previously in normal mice (Vuopio-Varkila et al., $1987 b$ ). The bacterial growth in the peritoneal cavity decreased by $2.5 \mathrm{~h}$ after an inoculum of 5 LD50 (fig. 5a), and by $5 \mathrm{~h}$ the numbers were below the detection limit of $10^{2} \mathrm{cfu} / \mathrm{ml}$ of fluid. This decline in the number of viable bacteria in the peritoneal cavity was accompanied by decreased blood (fig. 5b) and liver counts (data not shown).

\section{Discussion}

An experimental $E$. coli peritonitis-septicaemia model was adapted for use with neutropenic, immunosuppressed mice. Compared to the previously described systemic $E$. coli $\mathrm{O} 18: \mathrm{K} 1$ infection (Nowicki et al., 1986; Vuopio-Varkila et al., 1987a) 100 -fold smaller inocula $\left(4 \times 10^{3}\right.$ instead of $4 \times 10^{5}$ bacteria/mouse) were required to induce lethal infection. The immunosuppressed state of the animals resembled that seen in hospitalised patients receiving cancer chemotherapy. In both normal and immunosuppressed mice, the infection progressed rapidly without the need for adjuvants to increase the virulence of the $E$. coli.

A sublethal dose $(300 \mathrm{mg} / \mathrm{kg})$ of $\mathrm{CY}$ was chosen to induce neutropenia in the mice. The leukopenia

Table II. The effect of LPS-treatment on survival of immunosuppressed mice subjected to a lethal (5 LD50) E. coli $\mathrm{O} 18: \mathrm{K} 1$ challenge

\begin{tabular}{cc}
$\begin{array}{c}\text { LPS dose } \\
(\mu \mathrm{g})\end{array}$ & $\begin{array}{c}\text { Number of dead mice/total } \\
\text { challenged (and percentage) }\end{array}$ \\
\hline 5 & $3 / 12(25)$ \\
$0 \cdot 5$ & $11 / 24(46)$ \\
$0 \cdot 05$ & $8 / 12(67)$ \\
none & $15 / 15(100)$ \\
\hline
\end{tabular}




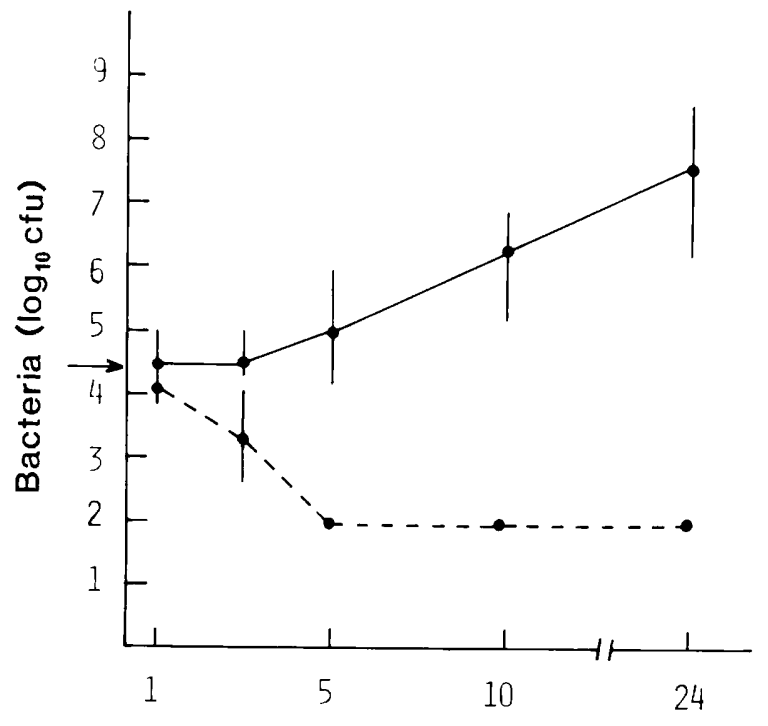

A

Time (h)

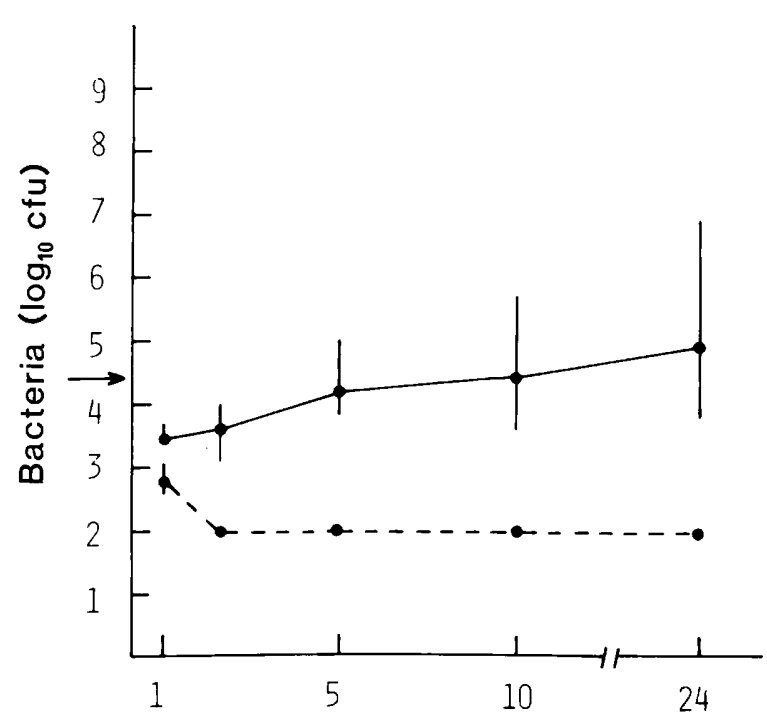

B

Time (h)

Fig. 5. The effect of LPS treatment on the kinetics of E. coli O18:K1 infection in immunosuppressed mice. (A) peritoneal cavity, (B) blood; (--) mice treated with $5 \mu \mathrm{g}$ of LPS, (- $(-)$ controls without LPS treatment. The challenge dose (5 LD50) is indicated by an arrow. Each point represents the geometric mean of results for three mice; the vertical lines show the ranges of values.

reached its nadir in the peripheral blood by days 2 3 and the leukocyte levels remained low until day 7 , which was the final observation day in the experiments. In the study of Petursson and Chervenick (1982), a dose of CY $200 \mathrm{mg} / \mathrm{kg}$ ip markedly decreased the total blood leukocyte levels, including neutrophils, and the number of megakaryocytes and granulocyte progenitors in the bone marrow and spleen for the same period. A high dose of CY, as used in the present study, also suppressed B and T cell proliferation (Turk and Parker, 1982), but had less effect on macrophage function. It is assumed generally that the main line of defence against extracellular pathogens such as $E$. coli or Klebsiella spp. is phagocytosis by polymorphonuclear leukocytes (Tatsukawa et al., 1979; Tsuru et al., 1981).

When the immunosuppressed mice were challenged with $E$. coli $\mathrm{O} 18: \mathrm{K} 1$ they were markedly more susceptible than normal mice, as evidenced by a 100 -fold decrease in LD50. A similar decrease in LD50 of $E$. coli $\mathrm{O} 18: \mathrm{K} 1$ is also seen after whole body irradiation (700 rad, 3 days before challenge) (unpublished data). Despite this increase in susceptibility, the immunosuppressed mice were still resistant to infection by a non-capsulated mutant of the $E$. coli $018: \mathrm{K} 1$ strain even when doses of $1 \times$ $10^{7}$ or $1 \times 10^{8}$ bacteria were injected ip (unpublished data). This is consistent with the role of $\mathrm{K} 1$ capsule as a virulence factor of $E$. coli (Kim et al., 1986). In
Klebsiella spp. (Trautmann et al., 1985) and $P$. aeruginosa (Tegtmeier and Andersen, 1983) peritonitis models, decreases in resistance of $1000-$ and 10fold, respectively, have been reported after a similar, single ip injection of CY.

In this infection model, a high inoculum (5 LD50) resulted in rapid bacterial growth in the peritoneal cavity. Bacterial counts in the blood followed the bacterial concentrations in the peritoneal cavity. If the inocula were smaller, the mice were able to restrict the growth of the bacteria and to clear them by $24 \mathrm{~h}$. In normal mice a similar restriction of bacterial growth seems to be a consequence of macrophage activation (Vuopio-Varkila et al., 1987b). Thus, even in the immunosuppressed mice, some defence mechanisms, e.g., the complementmediated killing of non-capsulate bacteria, capable of responding to the bacterial challenge, were functional despite an otherwise great reduction in resistance to infection.

Passive immunisation of the immunosuppressed mice with anti-capsular or anti-O18 antibodies resulted in increases in resistance to $E$. coli $018: \mathrm{K} 1$ infection of 50- and 5-fold, respectively. Both immune sera were as protective in the immunosuppressed mice as in the normal mice, when estimated by the volume of antiserum $(0.2 \mu \mathrm{l}$ of anti-K 1 or $20 \mu \mathrm{l}$ of anti-018 per mouse) needed for maximal protection (Vuopio-Varkila et al., 1987a). In the study of Trautmann et al. (1985) with a klebsiella 
peritonitis model in CY-treated mice, a large amount $(200 \mu \mathrm{l})$ of specific anti-klebsiella IgG antiserum produced a 100-fold increase in LD50 when administered shortly after bacterial challenge. In a pseudomonas infection model in granulocytopenic mice (Tegtmeier and Andersen, 1983) a serotype-specific anti-LPS antiserum only transiently delayed the otherwise lethal infection. However, Pierson et al. (1976) protected immunosuppressed mice against a 10 LD50 pseudomonas challenge by the transfer of a large amount $(200 \mu \mathrm{l})$ of pseudomonas immune serum.

The role of anti-K1 and anti-O18-LPS antibodies in protection against experimental $E$. coli $\mathrm{O} 18: \mathrm{K} 1$ infection in normal mice has been established by several studies (Bortolussi and Ferrieri, 1980; Cross et al., 1983; Vuopio-Varkila et al., 1987a), even by using monoclonal antibodies to these cell surface components (Pluschke and Achtman, 1985; Kaufman et al., 1986). In the klebsiella and pseudomonas models the antibody-mediated immunity is based on serotype-specific $\mathrm{O}$-antigen antibodies (Pierson et al., 1976; Tegtmeier and Andersen, 1983; Trautmann et al., 1985).

Anti-J5-antiserum directed against the coreglycolipid of LPS was no more protective against $E$. coli $\mathrm{O} 18: \mathrm{K} 1$ challenge in the immunosuppressed mice than it was in normal mice (Vuopio-Varkila et al., 1987a). The reason for its lack of efficacy is probably the same in both cases - the shielding effect of the capsule and smooth-type LPS, which prevent the binding of antibodies to deeper epitopes (Van der Ley et al., 1986; Vuopio-Varkila et al., $1987 a$ ).

LPS is an efficient modifier of the immune system. Since the early work of Landy (1956) and Abernathy (1957), it has become clear that host

\section{REFERENCES}

Abernathy R S 1957 Homologous and heterologous resistance in mice given bacterial endotoxins. Journal of Immunology $\mathbf{7 8}$ : 387-394.

Bortolussi R, Ferrieri P 1980 Protection against Escherichia coli $\mathrm{K} 1$ infection in newborn rats by antibody to $\mathrm{K} 1$ capsular polysaccharide antigen. Infection and Immunity 28:111117.

Buhles W C, Shifrine M 1977 Adjuvant protection against bacterial infection in granulocytopenic mice. Journal of Infectious Diseases 136: 90-95.

Cross A S, Zollinger W, Mandrell R, Gemski P, Sadoff J 1983 Evaluation of immunotherapeutic approaches for the potential treatment of infections caused by K1-positive Escherichia coli. Journal of Infectious Diseases 147: 68-76.

Elbein A D, Heath E C 1965 The biosynthesis of cell wall lipopolysaccaride in Escherichia coli. I. The biochemical resistance to infection can be non-specifically increased by an injection of LPS. In a recent study with granulocytopenic mice, Tegtmeier and Andersen (1983) showed that active immunisation with whole $P$. aeruginosa increased non-serotype-specific resistance to a subsequent pseudomonas challenge which lasted for 8 days after immunisation. This early-phase resistance was probably due to LPSinduced macrophage activation that increased their bactericidal capacity, whereas specific opsonising antibodies were shown to be important later, 12 days after the end of the immunisation. In the present study, a definite resistance-increasing effect of a subcutaneous K-12 LPS injection was shown in the neutropenic mice. The non-specific resistance was good, causing a five-fold increase in the LD50 of $E$. coli $\mathrm{O} 18: \mathrm{K} 1$. In normal, immunocompetent mice the LPS-induced resistance was even more effective (Vuopio-Varkila et al., 1987b). Because the CY treatment used to induce the immunosuppression has little effect on long-living cells, the increased resistance to $E$. coli $\mathrm{O} 18: \mathrm{K} 1$ was probably the result of macrophage activation. The LPStreatment did not increase the number of neutrophils in the blood or in the peritoneal cavity (data not shown), and their possible role as the effector cell responsible for bacterial killing is unlikely.

This observed LPS-mediated increase in resistance is interesting in view of the possibility of using a similar non-specific stimulation to prevent serious infections in immunosuppressed patients. Several problems are, however, inherent in the clinical use of LPS, otherwise generally known as endotoxin.

I thank P. H. Mäkelä and Harri Saxén for reviewing the manuscript. This study was supported by SITRA, the Finnish National Fund for Research and Development. properties of a uridine diphosphate galactose-4-epimeraseless mutant. Journal of Biological Chemistry 240: 1919-1925.

Galanos C, Lüderitz O, Westphal O 1969 A new method for the extraction of $\mathrm{R}$ lipopolysaccharides. European Journal of Biochemistry 9: 245-249.

Galelli A, Parant M, Chedid L 1977 Role of radiosensitive and radioresistant cells in nonspecific resistance to infection of LPS-treated mice. Journal of the Reticuloendothelial Society 21: 109-118.

Harvath L, Andersen B R 1976 Evaluation of type-specific and non-type-specific Pseudomonas vaccine for treatment of Pseudomonas sepsis during granulocytopenia. Infection and Immunity 13: 1139-1143.

Hunninghake G W, Fauci A S 1976 Divergent effects of cyclophosphamide administration on mononuclear killer cells: quantitative depletion of cell numbers versus qualitative suppression of functional capabilities. Journal of Immunology 117:337-342. 
Kaufman B M, Cross A S, Futrovsky S L, Sidberry H F, Sadoff J C 1986 Monoclonal antibodies reactive with K1encapsulated Escherichia coli lipopolysaccharide are opsonic and protect mice against lethal challenge. Infection and Immunity 52:617-619.

Kim K S, Kang J H, Cross A S 1986 The role of capsular antigens in serum resistance and in vivo virulence of Escherichia coli. FEMS Microbiology Letters 35 : 275-278.

Landy M 1956 Increase in resistance following administration of bacterial lipopolysaccharides. Annals of the New York Academy of Sciences 66:292-303.

Lumish R M, Norden C W 1976 Therapy of neutropenic rats infected with Pseudomonas aeruginosa. Journal of Infectious Diseases 133: 538-547.

Miller J H 1972 Experiments in molecular genetics. Cold Spring Harbor Laboratory, New York.

Nowicki B, Vuopio-Varkila J, Viljanen P, Korhonen T K, Mäkelä P H 1986 Fimbrial phase variation and systemic $E$. coli infection studies in the mouse peritonitis model. Microbial Pathogenesis 1 : 335-347.

Petursson S R, Chervenick P A 1982 Megakaryocytopoiesis and granulopoiesis following cyclophosphamide. Journal of Laboratory and Clinical Medicine 100:682-694.

Pierson C L, Johnson A G, Feller I 1976 Effect of cyclophosphamide on the immune response to Pseudomonas aeruginosa in mice. Infection and Immunity 14:168-177.

Pluschke G, Achtman M 1985 Antibodies to O-antigen of lipopolysaccharide are protective against neonatal infection with Escherichia coli $\mathrm{K} 1$. Infection and Immunity 49: 365370.

Reed L J, Muench H 1938 A simple method of estimating fifty per cent end-points. American Journal of Hygiene 27, 493497.

Saxén H, Mäkelä O 1982 The protective capacity of immune sera in experimental mouse salmonellosis is mainly due to IgM antibodies. Immunology Letters 5:267-272.

Swinscow T D V 1978 Statistics at square one, 4th edn. British Medical Association, London, pp 54-57.

Tatsukawa K, Mitsuyama M, Takeya K, Nomoto K 1979 Differing contribution of polymorphonuclear cells and macrophages to protection of mice against Listeria mono- cytogenes and Pseudomonas aeruginosa. Journal of General Microbiology 115: 161-166.

Tegtmeier B R, Andersen B R 1983 Mechanisms of lipopolysaccharide-induced protection against Pseudomonas sepsis in granulocytopenic mice. Reviews of Infectious Diseases 5 Suppl:S963-S970.

Trautmann M, Müller-Leutloff Y, Hofstaetter T, Seiler F R, Hahn H 1985 Experimental Klebsiella septicaemia in mice: treatment with specific antibodies from the rabbit alone and in combination with gentamicin. Infection 13:29-34.

Tsuru S, Nomoto K, Mitsuyama M, Zinnaka Y, Takeya K 1981 Importance of polymorphonuclear leucocytes in protection of mice against Escherichia coli. Journal of General Microbiology 122: 335-338.

Turk J L, Parker D 1982 Effect of cyclophosphamide on immunological control mechanisms. Immunological Reviews 65:99-113.

Van der Ley P, Kuipers O, Tommassen J, Lugtenberg B 1986 $\mathrm{O}$-antigenic chains of lipopolysaccharide prevent binding of antibody molecules to an outer membrane pore protein in Enterobacteriaceae. Microbial Pathogenesis 1 : 43-49.

Vuopio-Varkila J, Karvonen M, Saxén H 1988a The protective capacity of antibodies to various outer membrane components in a systemic mouse peritonitis model caused by Escherichia coli O18:K1. Journal of Medical Microbiology. In press.

Vuopio-Varkila J, Nurminen M, Phyälä L, Mäkelä P H $1988 b$ LPS-induced nonspecific resistance to systemic Escherichia coli infection in mice. Journal of Medical Microbiology. In press.

Weinstein M P, Murphy J R, Reller L B, Lichtenstein K A $1983 a$ The clinical significance of positive blood cultures: a comprehensive analysis of 500 episodes of bacteremia and fungemia in adults. II. Clinical observations with special reference to factors influencing prognosis. Reviews of Infectious Diseases 5:54-70.

Weinstein M P, Reller L B, Murphy J R, Lichtenstein K A $1983 b$ The clinical significance of positive blood cultures: a comprehensive analysis of 500 episodes of bacteremia and fungemia in adults. I. Laboratory and epidemiologic observations. Reviews of Infectious Diseases 5: 35-53. 